\title{
Documentation of Enggano People's Myths and Rituals in Order to Nation Resilience and Cultural Sustainability
}

\author{
Dr. Ike Iswary Lawanda \\ \{iswari@ui.ac.id\} \\ Department of Library Science and Information, Faculty of Humanities \\ Universitas Indonesia, Kampus UI Depok, 16424, Indonesia
}

\begin{abstract}
Myths and rituals have been the source of defense and security in the life of Enggano people (Engganese). Myths and rituals need to be preserved by the way of documentation. The problem is that documentation in the island of Enggano is limited on the government related activities in the subdistrict office. As a remote and outermost island, Enggano is $100 \mathrm{~km}$ apart from North Bengkulu province. Enggano development has been hampered yet the influence of modern information technology life has penetrated into the life of the young generation such as the Enggano language that has begun to fade among the younger generation. Efforts to prevent Enggano cultural erosion can be done by electronically documenting the myths and rituals following the development of the people's life style as well as preserving, maintaining and securing Enggano. Archival documents are the results of the recordings of local government and people's activities in doing their daily life. Nevertheless, the documents created in the local village's governmental office have not touched the documents recording the culture of the Enggano people which is the guide of the life and wisdom of Enggano ethnicity's members. The limited access for the provincial and central governments becomes one of the aspects in the monitoring the documentation of Enggano people's archives. The awareness and knowledge regarding the importance of documents also become a concern.
\end{abstract}

Keywords: Enggano, documentation, archive, ICT, nation resilience.

\section{Introduction}

Archival documents are the evidence of the existence of a community, people, and a government/state (Choo, 2003; Lawanda, 2017, 2018). Documents preserve myths and rituals, as well as being conserved using information technology to live on. Archives Electronic System/Sistem Elektronik Arsip (SEKAR) facilitates the documentation of the myths and rituals of Enggano ethnicity in the process of creation, storage, as well as utilization and access particularly for the people of Enggano and other people in general.

Enggano island also has various economic potentials that can be developed such as tourism, fishery and agriculture. Tourism activities can be developed such as mangrove tourism covering an area $\pm 1.414,78 \mathrm{Ha}$, fishery tourism, diving tour with an area of $\pm 5.097 \mathrm{Ha}$ coral reef, and the beauty of the beach and seagrass bed covering an area of $\pm 103,73 \mathrm{Ha}$. As for the potentials in fishing waters area in Enggano island produce abundance of fishery resources. Various types of big and small pelagic fishes, crustachea, demersal fishes, reef fishes, sea 
cucumbers and shellfish live in the waters of Enggano island. As for agricultural area, Enggano island has superior commodities namely cacao and banana (Source: Elucidation of the Regent of North Bengkulu Regency, 2016). Culture is the guidance of the Enggano ethnic group in maintaining and preserving the natural environment as the source of needs of life resources and survival as well as the source of natural disaster's threats considering that Enggano island is a small island in the outermost part of Indonesia. The Enggano people have to be able to take care of themselves and prepare themselves from various threats on their life in their remote location.

Enggano island is composed by bumpy hills, kart hills, land and swamps. The bumpy hills are located in the southeast area, rising between 170-220 meter, while the karst hills rising between 100-150 meter are located in northwest area showing typical morphology and which is dominated by limestones. In the northern part of Enggano, particularly in the coastal area are the swampy alluvial lowland with the elevation of 0-2 meter. Such natural structure requires consideration and preservation from and by Enggano people to be passed on to the next generations. Consideration and preservation of natural physical environment has been done by several myths and rituals. The myths and rituals have the objective of protecting all the natural environment of Enggano island.

The land formation shape of Enggano island in general can be said as from quite flat land to sloping land with a small number of relatively steep areas. The eastern part of the island is flatter compared to the western part. Proportionally it can be said that $63.39 \%$ of the island has gentle slope $(0-8 \%), 27.95 \%$ is slightly sloping (8-15\%) and the rest is sloping to steep (15$40 \%$ ). Based on the land classification, the land of Enggano island is dominated by cambisol, latosol and alluvial soil types. Additionally, the soil of Enggano island has clayey plate texture.

In the area of Enggano island there are several rivers whose waters are generally influenced by the seasons. During rainy season, the river water discharge is high; whereas in dry seasons the discharge is low. The rivers are Kikuba river, Kuala Kecil river, Kuala Besar river, Kahabi river, Kinono river, and Berhawe river. Some other smaller rivers, among others are Kaay river, Kamamum river, Maona river and Apiko river.

Coastal characteristics in Enggano island can be categorized into 5 (five) main types namely muddy sand, sandy, coral sand, muddy coral sand, and rocky coral beach. The coastal characteristics of Enggano island are closely related to the existence of coral reef and mangrove ecosystems. Muddy sandy beach type is found in Kahyupu, Tanjung Harapan, and the estuary of Banjarsari river to Teluk Berhau. Coral sandy beach type is found in Kaana and Meok, whereas muddy coral sandy beach type can be found in Malakoni and Banjarsari. Rocky coral beach can be found in the easter part of Enggano island. Enggano island's climate is wet tropical which is greatly affected by the sea. Rainfall level during dry seasin still reaches above $100 \mathrm{~mm}$. The dry season usually comes in June and July. The wet season's rainfall level sometimes reaches more than $400 \mathrm{~mm}$ per month. Daily average air temperature ranges between $27.8{ }^{\circ} \mathrm{C}$ with the lowest temperature of $23.2{ }^{\circ} \mathrm{C}$ and the highest at $34{ }^{\circ} \mathrm{C}$. The relative humidity is generally above $80 \%$ with the lowest variation of $78 \%$ and the highest $96 \%$. This shows that air humidity in Enggano island is relatively high throughout the year. Natural wealth and the surrounding climate need to be maintained to avoid the possibility of destruction.

The Enggano ethnic group is divided into five original puaks (locals call it suku). All of them speak Engganese/Enggano language (Edwards, 2015). Suku or Puak Kauno / Kauno ethnic group started inhabiting this place during the Dutch era (around 1934). Besides the Kauno ethnic group, there are Banten ethnic group (immigrants), and four other ethnic groups. Enggano people generally live from cacao and pepper plantations to be sold to Bengkulu City. The largest plantation in Enggano is a banana plantation to be sold to Lampung Province. 
Complete disclosure of problems faced by the partners. The meanings of myths and rituals have already thinning out among the young people of Enggano. The problem is reflected from the younger generations who do not know and do not speak Enggano language. Language cannot be separated from myths and rituals. Language preservation through myths and rituals can be carried out through documentation. Documentation is supported by a system in the form of application for database, wide access outreaching territorial borders, and as a way of implementating preservation and control of Enggano myths and rituals and documents of both myths and rituals.

The issue comes out of ignorance and indifference on the organization and preservation of documents as evidence and containing the values of collective memory, identity, and history (Schwartz, 2002) of a community and the people of Enggano. Document becomes crucial when local people and the government faces changes caused by development. Document becomes important for ENggano people as part of organizational structure of the government of Republic of Indonesia becomes a shield in development. The challenges of development in Enggano island are: 1) Enggano island has not been established as national border area in 2015-2019, considering that the island is not directly bordered with other country instead it bordered with open ocean; 2) tourism potential has not been managed well, even though Enggano island has high biodiversity both forest and coastal ecosystems; 3) electicity, clean water, and fuel distribution is still limited thus it hampers people's economic activities; 4) Enggano island is the outermost island and one of the subdistrict of North Bengkulu Regency which is located in Sumatera mainland; 5) connectivity between villages in Enggano Island is still lacking, including connectivity from Enggano Island to the mainland of Sumatra or the capital city of North Bengkulu Regency; 6) Enggano Island has several villages with underdeveloped village typologies, even though North Bengkulu Regency is not a disadvantaged area; 7) unavailabity of basic services in several villages on Enggano Island; and 8) the potential for disaster threats in the form of tsunamis, earthquakes, abrasions / tidal waves and extreme weather.

As stated in Presidential Regulation No. 78 of 2005 regarding Management of Small Outermost Islands, Enggano island is one of the 92 small outermost islands stipulated in the Regulation. The development in Enggano island as small outermost island is carried out by the principles of Archipelagic Outlook / Wawasan Nusantara (that is) Sustainable, and Community based which is aimed to: (1) maintain the territorial integrity of the Republic of Indonesia, national security, state and national defense, and create regional stability; (2) utilize natural resources in the course of sustainable development; and (3) empower the community in order to improve welfare.

In line with the description above, the mandate of Presidential Regulation No. 2 of 2015 concerning the Rencana Pembangunan Jangka Menengah (RPJMN) / Medium Term Development Plan for 2015-2019 in order to realize security and defense on Enggano Island, TNI personnel will be placed to prevent security disturbances and violations of laws that threaten sovereignty of the state. As for realizing the utilization of sustainable natural resources, Enggano island becomes one of the priority locations for community service program, development and implementation of science and technology to support biological resources' sustainability and usefulness. Enggano island is selected because it is considered as the candidate for international shipping lines with high endemicity. Additionally, Enggano island is also one of the outermost islands thus the limited control often threatens the biodiversity. In this case exploration activities will be carried out in Enggano island as an attempt to study the condition of biodiversity preservation in the island.

The increased documentation on the physical activities and usage of Enggano ethnic group's myths and rituals gives birth to local wisdom in protecting and maintaining the 
community's environment and life to be able to be passed on the next generations. The issue of documents that function as evidence to a state sovereignty (Bradsher,1984: 57). The sovereignty of the Republic of Indonesia on the life of the human community and natural environment is clearly has not been touched in the direction of government policy in various government regulations. Thus, the activities of community services become urgent with the urgency of realizing security and defense. Additionally Enggano development has to be anticipated so that modernization which will encourage the Enggano people's natural and social environment life will be maintained and will maintain the Enggano local wisdom.

The community service is based on the specific objectives of the program namely, 1 . Implementation of Science and Technology is to assist the development of independent community group. 2 . Development od technology and innovation prototype implementation that can be implemented in accordance with the problems in the community. After the program is implemented, it is expected to be able to meet the target of Science and Technology, at least in three indicators of the improvement of empowerment and independency in the community as following: 1. motivators who have the understanding, affection, and skills of empowering the local people 2. The transformation of awareness, commitment, willingness, knowledge, skills, and affection of motivators on environemental issues 3. To mobilize local people in development of the society in wide.

\subsection{Partners Issues}

Partner priority issue is documentation that needs to be improved as the means and strategy to maintain and secure the environment and culture of Enggano people in facing the development. Documentation of physical activities and usage of myths and rituals supports the realization of resilience and security of Enggano natural environment and people. The government program of nawa cita (Nine Priorities) describes changes toward Indonesia's sovereignty in all aspects, with the consideration on marginalized and outermost village development, such as Enggano island. Supervision and control for resilience and security do not merely utilize military force, but archival documents. Myths and rituals function as cultural resilience and social security. It is implicitly stated in item 3.6.10 in nawa cita.

Ministry of Marine and Fisheries Regulation (Permen KP) No. 48 of 2015 regarding General Guidelines for Integrated Marine and Fisheries Center Development in Small Islands and Border, the Integrated Marine and Fisheries Center Development (PSKPT) program is aimed to strengthen upstream and downstream sctors and the institutions that encourage marine and fisheries businesses in small islands and border areas. The PSKPT program covers:

(1) SKPT area structuring through zoning plan preparation;

(2) masterolan preparation and business plan preparation;

(3) providing assistance and revitalization of production facilities and infrastructures in marine and fisheries area;

(4) providng marine and fisheries business capital assistance;

(5) strengthening marine and fisheries business institutions by developing systems for marine and fisheries business, coordination across ministries/institutions, guidance, assistance, and partnerships;

(6) provisions of facilities, means and infrastructures for marine and fisheries business;

(7) strengthening the competitiveness through the improvement of added value and marketing of marine and fisheries products;

(8) development of techno park through strengthening of science and technology role in supporting the processing of fisheries products and marine services; 
(9) marine and fisheries community's education, training, counselling, and empowerment;

(10) developing fish quarantine system, quality control, fisheries product safety, and fish biosafety;

(11) developing marine and fisheries science and technology;

(12) management of marine conservation area in the course of maintaining the preservation of fishery resource to support marine and fishery business as well as marine tourism; and

(13) increasing the supervision of marine and fishery resource. The PSKPT program is in line with one of the missions in Nawa Cita, which is development of marginal areas to strengthen the region, remote area and rural areas within the frame of Republic of Indonesia.

The development effort of Enggano island as one of the Indonesia's Small Outermost Islands/Pulau-pulau Kecil Terluar (PPKT) is aimed to answer various developmental challenges in the area, i.e. the effort to realize resilience and security, sustainable natural resources' utilization, as well as people's welfare improvement.

Given the cross-sectoral development challenges of Enggano Island, the success of development on Enggano Island requires cooperation, support, and synergy from all stakeholders, both the governmental (central and regional) and non-governmental. All development programs and activities can work with existing documents and ongoing documentation using information technology.

\subsection{Method}

The community service program of the increase of myths and rituals documentation is the answer to various development challenges in the area of Enggano, namely the efforts to realize resilience and security, sustainable natural resource utilization, and also the community's welfare improvement. The solution is done together with the source persons who are the elders and/or representatives of Enggano ethnic group mastering or understanding the content and context as well as the benefits of Enggano myths and rituals in series of activities.

All activities include representatives of Enggano's three ethnic groups, namely the women representing dasa wisma, and representatives of the subdistrict, except for data transferring process from monolog to analog in Jakarta is carried out by research team. People of Enggano ethnic group is considered as source of knowledge and information on myths and rituals related to natural environment, natural treasure contained in Enggano island, and the air too.

\section{Analysis}

Priorities of issues resolved with the partners are,

Increasing the activities and utilization of Enggano population in general and Enggano ethnic group in particular, in the documentation of myths and rituals as the efforts of cultural preservation. Basically, people of Engganese, as an ethnic group has had manuscripts of their own kept, but rarely and has not been structured as evidential entity. There are requirements necessary to become evidential documents legitimate such as codified and indexed by authority concerning the local government validation. In this case, Enggano is under the authority of Bengkulu Utara city, Bengkulu provincial authority. 
Electronic documents are disseminated to Enggano, Bengkulu, and throughout Indonesia using the Archive Electronic System (SEKAR) application.

Documentation and electronic documents of myths and rituals become a way and a way to solve problems against the country's challenges in the security and security of the nation.

Documents as evidence of the activities of Enggano people living in the outermost regions of the territory of Indonesia are becoming evidences of Enggano islanders under the sovereignty of the Unitary State of the Republic of Indonesia. Documents of myth and ritual are manifestations of national ownership, advocacy, and national identity.

The program target resulting from each solution mentioned earlier can be seen from activities and success indicators as following,

Table 1. Activity Process.

\begin{tabular}{|c|c|c|}
\hline Type & Activity & Indicator \\
\hline Raw Material & Myths \& rituals; knowledge; information & $\begin{array}{lr}\text { Electronic } & \text { documents; } \\
\text { archival description of } \\
\text { documents } & \text { Dokumen } \\
\text { elektronik; } & \text { deskripsi } \\
\text { kearsipan } & \text { dokumen; } \\
\text { electronic } & \text { system } \\
\text { application of } & \text { myths \& } \\
\text { rituals; server } & \\
\end{array}$ \\
\hline \multirow[t]{3}{*}{ Product } & $\begin{array}{l}\text { Recording of myths and rituals both audio } \\
\text { and virtual }\end{array}$ & $\begin{array}{l}\text { Documents of Enggano } \\
\text { culture }\end{array}$ \\
\hline & Access & System application \\
\hline & $\begin{array}{l}\text { Creation of the archival description of } \\
\text { Enggano cultural myths and rituals } \\
\text { documents }\end{array}$ & $\begin{array}{l}\text { Guidelines for } \\
\text { classification and Relative } \\
\text { Index of Enggano Culture } \\
\text { documents }\end{array}$ \\
\hline Database & Transferring documents into application & $\begin{array}{l}\text { Enggano culture archives } \\
\text { electronic system }\end{array}$ \\
\hline $\begin{array}{l}\text { Human } \\
\text { Resource }\end{array}$ & $\begin{array}{l}\text { Two lecturers, } 1 \text { educational personnel, } 4 \\
\text { students }\end{array}$ & $\begin{array}{l}\text { Service for } \begin{array}{r}\text { Science and } \\
\text { Technology community } \\
\text { program }\end{array} \\
\end{array}$ \\
\hline $\begin{array}{l}\text { Quality } \\
\text { Assurance }\end{array}$ & $\begin{array}{l}\text { Link of application in the server of } \\
\text { governmental information site of the } \\
\text { North Bengkulu subdistrict, Bengkulu } \\
\text { Province; Archive description of the } \\
\text { documents; classification }\end{array}$ & Document access \\
\hline Target & $\begin{array}{l}\text { Electronic documents through the } \\
\text { application are owned and used by each } \\
\text { inhabitant of Enggano }\end{array}$ & Application is operating \\
\hline
\end{tabular}

\subsection{Application And Needs Identification}

The provincial government office in this case Enggano sub-district, North Bengkulu Regency, has the authority to make archival document policies and standards in the sub-district 
environment. This includes the management of electronic records to ensure fast and accurate information services.

On the basis of the information needs of application users, service providers will carry out identification related to available information technology that can meet those needs. Based on community, the project involves certain people from various levels, from representatives of the Enggano people and approval from the head of the North Bengkulu district.

The preparation phase of development and adjustment of applications for electronic archival system needs can be done already in Enggano community particularly and Bengkulu community in general. The initial stage of identification was carried out from the beginning by the server team together with the North Bengkulu sub-district office, continued to be done together with representatives of three Enggano ethnic groups, throughout and after the program end.

From the results of the final task a conclusion can be drawn that the application provides convenience in the case of search and retrieval. The variety of search points is also provided in the application so it makes information searching easy in accordance with the desired category or subject. The feature to connect the relationship between documents has been designed in the application thus it can contextually and comprehensively explain/describe the document.

\subsection{Installation}

Installation is carried out by coordination with the information system development subdriectorate of Enggano subdistrict office, North Bengkulu Regency. Installation development uses on server that is similar to the web server of bengkuluutarakab.go.id. Nevertheless, with the developing needs for performance improvement, it is then installed to the server (VMVirtual Machine) of North Bengkulu regency.

\subsection{Taxonomy Adjustment}

For the needs in the community of Enggano people, undoubtedly display adjustment is required for users that will make data input easier for the officers. The main concern in the adjustment is the use of terms to be applied. SEKAR which is the application basis for the SEKAR development used international standard on archival description namely the International Standard Archival Description - General or abbreviated to ISAD-(G).

The standard as the identification result has met the documents and archives description needs in three Enggano ethnic groups. Neverthelss since the standard use s general language, terms adjustment is required for the management of myths and rituals documents in Enggano. For the convenience of the users from Enggano community to be able to understand SEKAR, server team also translates the manual of SEKAR usage. Both translations are expected to increase the use of SEKAR and the number of contributors so that the development of the application can be more dynamic.

\subsection{User Manual}

With the increasing SEKAR data and users, users' manual has to be made, therefore we together with the representatives of the three ethnic groups and subdistrict office as well as the ethnic group's elders design a manual that is aimed to make SIK easier for the users to be understood. 
The concern of document management is also directed more to the static archives. The displayed field in the input process is simplified into 5 main categories:

Archive description input field category; 2. General information; 3. Description adjusted to condition; 4. Identity area; 5 . Context area.

Searching Point, there are only 2 elements used, namely classification (subject) and unit location (place); Administration Area, adjustment is carried out in the part of archive status and availability; "Status" to describe whether the archive is static, reviewed, inactive, etc. While "archive availability" icon is used to address the archive is available or not.

The strategy of the sustainability of Science and Technology Service program for the community in the form of increasing activities and utilization of the documentation of myths and rituals of Enggano ethnic group living in the outmost and remote island in Indonesia is in harmony with the sustainable development target. Myths and rituals documents support, control, secure, and maintain sustainable development which includes the effort to realize the occurrence of: (a). Equitable distribution of benefits from intergeneration equity, which means that the use of natural resources for growth needs to consider the reasonable limits in the control of ecosystems or environmental systems and is directed towards replaceable natural resources and emphasizes the lowest possible exploitation of irreplaceable natural resources. (b). Safeguarding the preservation of the existing natural resources and environment and preventing the occurrence of ecosystem disturbance in the course of guaranteeing the quality of life remains good for the future generations. (c). The utilization and management of natural resources is solely for the interest of catching up with the economic growth for the interests of equitable distribution of sustainable natural resource utilization between generations. (d). Maintaining people's sustainable welfare both for the present and the future (inter temporal). (e). maintaining the benefits of development as well as the natural and environmental resources which has long termed benefits or ever lasting between generations (f). Maintaining the quality of human life amongst is becoming into consideration in accordance with their habitats.

The continuation of the activities of documenting and utilizing myths and rituals documents of the Enggano people using the Enggano People's Cultural Documents application needs to be maintained, after this science and technology program is completed. Sustainability has characteristics (1). Utilities obtained by the community do not diminish over time and consumption does not decrease over time; (2) natural resources are managed in such a way as to maintain opportunities for production in the future; (3) conditions where natural resources do not decrease over time; (4) natural resources are managed to maintain the production of natural resource services; (5) the balance and resilience of the ecosystem are fulfilled.

The importance of Enggano people's myths and rituals documents maintains the sustainable development and future generations' awareness and central/regional government requires accurate strategy which is to open the access to the Enggano myths and rituals document utilization for the entire community of Enggano, Enggano, Bengkulu, Indonesia, regional, and international people. This open access is equipped with control over documentation activities which are limited to representatives of the Enggano ethnic group appointed by the Enggano ethnic group themselves. Open access to the use of applications containing the principles of sustainable development strategies, namely equity, participation, diversity, integration, and a long-term perspective. 


\section{Conclusion}

The solution to the problems faced by the Enggano people as a contributing community in the Unitary State of Republic of Indonesia (NKRI) is carried out by improving the documentation of Enggano people's myths and rituals. The documentation of Enggano people's life has undoubtedly taken place around the government offices. Yet the documentation of Enggano people's life activities needs to be improved at the level of general residents. The effort is to make the local people to document their daily life through myths and rituals that are inherent in the life of each individual of the Enggano people. Some Enggano people and representatives of the village office have been involved from the early stage to the last stage.

The efforts are recommended to take steps starting from the first step for the team took care of the licensing with the North Bengkulu district government, particularly the subdistricts in North Bengkulu regency with its governmental center in Apoho village and three ethnic groups (puak) in three villages, as well as explaining the activities that would take place. Second step, the documentation of myths of each ethnic group (puak) goes along with the rituals that were in progress during the documentation using information technology involved Enggano people, representatives of each ethnic group until the end of the program. Thirdly, the recording/documentation result's examination involved representatives of each Enggano ethnic groups. Fourth, the creation of the document's archival description was carried out together with representatives of each ethnic group. Fifth, myths and ritual documents input was done using SEKAR archival information system or application together with representatives of the three ethnic groups. Sixth, the improvement of application usage which had commenced to be on trial since the final process of step five. Seventh, the creation of document list by representatives of the three ethnic groups accompanied by research team. Eighth, the handover of the result of the program overhands to the three ethnic groups, the government of Enggano subdistrict, and the regency of North Bengkulu.

\section{References}

[1] Bradsher, G. (1989). Management Archives \& Archival Institutions. Chicago: The University of Chicago.

[2] Choo, C.W.(2003). Perspectives on Managing Knowledge in Organizations dalam Cataloging \& Classification Quartery, Vol. 37, No. 1/2, 2003, pp. 205-220

[3] Edwards, O.(2015). The position of Enggano within Austronesian dalam Oceanic Linguistics, Vol.54, No.1.

[4] Lawanda, I.I.(2017)(ed.). Arsip, kepemilikan bangsa, dan budaya. Jakarta: Sagung Seto.

[5] Lawanda, I.I. (2018). Institusionalisasi profesi pengelola rekod: perwujudan dari jaringan tata kelola. Jakarta: MALES ARTS.

[6] Republik Indonesia (2005). Peraturan Presiden No. 78 Tahun 2005 tentang Pengelolaan PulauPulau Kecil Terluar

[7] Republik Indonesia (2010). Peraturan Pemerintah Nomor 62 Tahun 2010 tentang Pemanfaatan Pulau-Pulau Kecil Terluar.

[8] Republik Indonesia (2015). Peraturan Menteri KP No. 48 Tahun 2015 tentang Pedoman Umum Pembangunan Sentra Kelautan dan Perikanan Terpadu di Pulau-Pulau Kecil dan Kawasan Perbatasan [9] Republik Indonesia (2015). Peraturan Menteri KP No. 48 Tahun 2015 tentang Pedoman Umum Pembangunan Sentra Kelautan dan Perikanan Terpadu di Pulau-Pulau Kecil dan Kawasan Perbatasan [10] Republik Indonesia (2015). Peraturan Presiden No. 2 Tahun 2015 tentang Rencana Pembangunan Jangka Menengah (RPJMN) Tahun 2015-2019 guna mewujudkan keamanan dan pertahanan di Pulau Enggano. 
[11] Republik Indonesia (2016). Peraturan Presiden No. 45 Tahun 2016 tentang Rencana Kerja Pemerintah (RKP) Tahun 2017.

[12] Richardson, B.(2012). Record management for dummies. New Jersey: John Wiley.

[13] Sari, I.P.(2017). Harmoni Dalam Kebhinekaan (Kearifan Lokal Masyarakat Pulau Enggano Provinsi Bengkulu Dalam Mengatasi Konflik). Jurnal Antropologi: Isu Isu Sosial Budaya. Desember 2017 Vol. 19 (2):139-147

[14] Swartch, J. dan Cook, T.(2002). Archives, Records, and Power: The Making of Modern Memory dalam Archival Science 2: 1-19, 2002. 